\title{
COMPARATIVE PHYTOCHEMICAL ANALYSIS OF ALPINIA OFFICINARUM RHIZOME AND TERMINALIA CHEBULA FRUIT
}

\author{
Krishnaveni $\mathbf{M}^{1}$, Aishwarya $\mathrm{PG}^{2}$ and Aparna $\mathrm{KR}^{2}$ \\ ${ }^{1}$ Assistant Professor, Department of Biochemistry, Periyar University, Salem-636- 011 \\ ${ }^{2}$ M.Sc Student, Department of Biochemistry, Periyar University, Salem-636- 011
}

\begin{abstract}
*Corresponding Author Email: logan.consolidated@gmail.com
ABSTRACT

Rhizomes and fruits form a drug and medicinal plants are the future as they lack side effects, each parts of plants require proper research to know its importance. Hence, the present study was undertaken to analyse. Alpinia officinarum rhizome and Terminalia chebula fruit both qualitatively and quantitatively. Qualitative phytochemical analysis showed positive result for most of the tests assessed. And FTIR showed positive result for flavonoid, saponin, tannin. Similarly, HPLC was tested for flavonoid and shows positive peaks for flavonoid. Both the samples tested showed good antioxidant scavenging activity, phenolics in large amount, while lesser nutrient content. The results obtained shows, that it has to be researched further for the purposive uses like skin disorders etc.
\end{abstract}

\section{KEY WORDS}

Antioxidants, Fruit, FTIR, HPLC, Rhizome

\section{INTRODUCTION}

Natural products are good resources for medicinal compounds. Plants were in use by 1.5 million practitioners for remedial measures. Around 2000 tonnes of herbs was consumed by 7800 drug synthesis unit, the top users were China and India. ${ }^{1-4}$ For its antiinflammatory, antibacterial, antifungal, antiviral, diuretic, and anticancer properties..$^{5-6}$ Alpinia officinarum rhizome and Terminalia chebula fruit contain flavonoids. Flavonoids like quercetin, kaempferol, galangin, protect against oxidative stress through antioxidative protein expression. Flavonoid alters the frequency of free radicals generated by radical scavenging, metal chelating activity, xanthine oxidase inhibition, increased endogenous antioxidants. ${ }^{7-9}$ Presence of several phytochemicals allows its use in ayurveda, unani, homeopathy too. ${ }^{10-12}$ $\mathbf{2 0 - 5 0 \% ~ t a n n i n s ~ i n ~ T e r m i n a l i a ~ c h e b u l a , ~ i m p a r t ~}$ pharmacological activity. ${ }^{13-15}$ Since, Alpinia officinarum rhizome and Terminalia hebula fruit possess pleiotropic properties, it was decided to study the phytochemicals both qualitatively and quantitatively. Hence, the present study was focused much on analytical (FTIR,
HPLC), biochemical analysis (Phytonutrients, Secondary metabolites, Antioxidant activity) in Alpinia officinarum rhizome and Terminalia hebula fruit.

\section{METHODS}

\section{Sample collection}

Samples were purchased from local herbal shop at Salem, Tamil Nadu, India.

\section{Extract preparation}

Aqueous extract was prepared by dissolving $15 \mathrm{~g}$ of powdered Alpinia officinarum rhizome and Terminalia hebula fruit powder in $200 \mathrm{ml}$ water or laboratory use and heated on a hot plate (constant stirring) at $30-40^{\circ} \mathrm{C}$ for 20minutes, cooled and filtered through filter paper and used for qualitative, ${ }^{16-18}$ antioxidant, phytonutrient analysis by adopting standard procedures.

\section{QUALITATIVE ANALYSIS}

\section{Test for Glycosides:}

To the extract added aqueous $\mathrm{NaOH}$. Formation of yellow color indicates glycosides.

\section{Test for flavonoids:}

In a test tube containing $0.5 \mathrm{ml}$ of extract, 5-10 drops of dilute $\mathrm{HCl}$ and $\mathrm{ZnCl}$ or magnesium were added the 
solution was boiled for a few minutes. Presence of reddish pink or dirty brown color confirms flavonoid.

Test for Saponins:

In a test tube containing $0.5 \mathrm{ml}$ of aqueous extract, a drop of sodium bicarbonate was added, shaken vigorously. Appearance of froth confirms saponins.

\section{Test for Steroids:}

To $2 \mathrm{ml}$ of chloroform extract, $1 \mathrm{ml}$ of concentrated $\mathrm{H}_{2} \mathrm{SO}_{4}$ was added carefully along the sides of the test tube. Appearance of red color in the chloroform layer confirms steroids.

\section{Test for Carbohydrate}

Molisch test:

To the extract added few drops of alcoholic alpha naphthol solution. Few drops of concentrated sulphuric acid was added along the sides of test tube to get a violet colored ring at the junction.

\section{Fehling's test:}

To the extract added equal amount of Fehling's A and B solution and then the tubes were kept in a boiling water bath. Brick red precipitation of cuprous oxide formation confirms reducing sugar.

Test for Tannin and Phenolic compound:

\section{Ferric chloride test:}

To the extract added ferric chloride. Greenish black color confirms a positive result.

\section{Potassium dichromate test:}

To the extract added potassium dichromate solution. Positive result was confirmed by brown precipitate formation.

\section{Oil test:}

Blue color denoted positive result when the extract was mixed $1 \mathrm{ml}$ of $1 \%$ copper sulphate and $10 \%$ sodium hydroxide.

\section{Fourier transform infrared analysis Sample preparation}

For FT-IR analysis, the samples were ground in a mortar and pestle to reduce the average particle size to 1 or 2 microns. The Fourier transform infrared spectrum was recorded using FT-IR - AGILENT - Model Number: CAP15T at Tamil Nadu Test House PVT Limited, Chennai.

HPLC

High performance Liquid Chromatography was performed at Tamil Nadu Test House PVT Limited, Chennai using AGILENT- Model Number :1100 With DAD.

\section{SECONDARY METABOLITES}

The phenol and flavonoid content of aqueous leaf extract was analysed.

\section{Determination of Total phenol content}

Total phenolic content was determined by Folilciocalteau method Nabavi et.al (2008). ${ }^{19}$ To $0.1 \mathrm{ml}$ of extract add folin ciocalteau reagent $(5 \mathrm{ml}, 1: 10$ diluted with distilled water) stand for $5 \mathrm{~min}$ and aqueous $\mathrm{NaCO}_{3}$ $(4 \mathrm{ml}, 1 \mathrm{M})$ was added, incubated for $15 \mathrm{~min}$. The phenol liberated was determined by colorimetric method at $765 \mathrm{~nm}$. The standard curve was prepared, expressed in terms of Gallic acid equivalent (mg/g of dry mass).

\section{Estimation of flavonoids}

Aluminium chloride method Mervat et.al (2009) ${ }^{20}$ was used for the determination of the total flavonoid content. To $0.1 \mathrm{ml}$ of extract added $0.1 \mathrm{ml}$ of $\mathrm{AlCl}_{3}(10 \%)$. The test solution was vigorously shaken. Absorbance at $415 \mathrm{~nm}$ was recorded after $30 \mathrm{~min}$ of incubation. The concentration of flavonoid in the test samples were calculated from the calibration plot and expressed as mg quercetin equivalent/g of sample.

\section{ANTIOXIDANT ASSAYS}

Nitric oxide scavenging assay, reducing power, Total antioxidant assay was performed.

\section{Nitric oxide scavenging activity}

Nitric oxide scavenging activitywas estimated. ${ }^{21}$ Sodium nitroprusside $(10 \mathrm{mM})$ in phosphate buffered saline was added to $0.1 \mathrm{ml}$ of extract and kept at RT for $150 \mathrm{~min}$, followed by addition of $0.5 \mathrm{ml}$ of Griess reagent. The absorbance was read at $546 \mathrm{~nm}$. Quercetin was used as a reference compound.

\section{Reducing power assay}

Reducing power assay was performed. ${ }^{22}$ To $0.1 \mathrm{ml}$ of extract, phosphate buffer $\left(2.5 \mathrm{ml}, 0.2 \mathrm{M}, \mathrm{P}^{\mathrm{H}} 6.6\right)$ and potassium ferric cyanide $(2.5 \mathrm{ml} 1 \%)$, incubated for $20 \mathrm{~min}$ at $50^{\circ} \mathrm{C}, 1.0 \mathrm{ml}$ of trichloro acetic acid (10\%) was added to stop the reaction, centrifuged at 3000rpm for $10 \mathrm{~min}$. To $1.5 \mathrm{ml}$ of upper layer solution add $1.5 \mathrm{ml}$ distilled water and $\mathrm{FeCl}_{3}(0.1 \mathrm{ml}, 0.1 \%)$, contents were mixed and incubated for $10 \mathrm{~min}$ and the absorbance was measured at 700nm. Vitamin $C$ was used as a positive control.

\section{Total antioxidant capacity}

Total antioxidant capacity assay ${ }^{23}$ is based on the reduction of Mo (V1) to Mo (V) by the analyte allowing green phosphate/Mo (V) complex at acidic $\mathrm{pH}$. The total antioxidant activity is expressed as equivalents of ascorbic acid. 


\section{Analysis of phytonutrients}

Total carbohydrates, proteins, amino acids were performed according to the standard prescribed methods.

\section{Estimation of carbohydrate}

The total carbohydrate was estimated. ${ }^{24}$ To $0.1 \mathrm{ml}$ of extract, add $4 \mathrm{ml}$ of anthrone reagent, heat for 810 minutes in a boiling water,cooled and read at $630 \mathrm{~nm}$ using spectrophotometer Schimadzu Model - UV 1800. Glucose forms a standard.

\section{Estimation of protein}

The total protein was estimated. ${ }^{25}$ To $0.1 \mathrm{ml}$ of extract, add $2 \mathrm{ml}$ of alkaline copper reagent, mixed well and kept for 10 minutes, followed by $0.2 \mathrm{ml}$ of Folin ciocalteau reagent (diluted in the ratio of $1: 2$ ), incubated for 30 minutes, read at $660 \mathrm{~nm}$ using spectrophotometer Schimadzu - Model UV 1800. BSA was used as a standard. With the standard graph, unknown concentration was studied.

\section{Estimation of aminoacids}

The amino acid was estimated ${ }^{26}$ To $0.1 \mathrm{ml}$ of extract, add $1 \mathrm{ml}$ of ninhydrin solution dissolved in Butanol: Acetone. Close the tubes to avoid evaporation. With mild stirring, heated at $80-100 \circ \mathrm{C}, 4-7$ minutes. Cooled and read at $570 \mathrm{~nm}$. Tyrosine standard was used.

\section{STASTICAL TOOL}

The Mean and Standard deviation (S) was calculated by using the following formula:

Mean $=$ Sum of $\mathrm{x}$ values $/ \mathrm{n}$ (Number of values)

$$
s=\frac{\sqrt{\sum(X-M)^{2}}}{n-1}
$$

\section{Antibacterial assay}

\section{Preparation of Inoculum:}

The Escherichia coli, Bacillus punilus, Salmonella typhimurium, Staphylococcus aureus were pre-cultured in nutrient broth overnight in a rotary shaker at $37^{\circ} \mathrm{C}$, centrifuged at10,000 rpm for $6 \mathrm{~min}$, pelletwas suspended in double distilled water and the cell density was standardized spectrometrically (A $\mathrm{nm}$ ).

\section{Preparation of test sample:}

For the anti-microbial tests, extracts were diluted in dimethyl sulfoxide (DMSO): Methanol (1/1: v/v) solvent to a concentration of $20 \mathrm{mg} / \mathrm{ml}$. Anti-bacterial activity was measured using agar dilution technique. Briefly the extracts were dissolved in dimethyl sulfoxide (DMSO, Merck) and serially diluted in molten Muller Hinton Agar (MHA, Sigma) in petridishes $(100 \mathrm{~mm} \times 15 \mathrm{~mm})$. The solvent did not exceed $1 \%$ concentration and did not affect the growth of the organisms. For bio-assays, suspension of approximately $1.5 \times 10^{8}$ bacterial cell $/ \mathrm{ml}$ in sterile normal saline were prepared and about $1.5 \mathrm{ml}$ of was uniformly seeded on Muller-Hinton-Agar medium with $3-4 \mathrm{~mm}$ thickness in $12 \mathrm{~cm} \times 1.2 \mathrm{~cm}$ glass petri dishes, left aside for $15 \mathrm{~min}$.and excess of suspension was then drained and discarded properly. Wells of $60 \mathrm{~mm}$ in diameter and about $2 \mathrm{~cm}$ apart were punctured in the culture media using sterile cork bores. Well were filled with $0.1 \mathrm{ml}$ of each $20 \mu \mathrm{g} / \mathrm{ml}$ concentration of each sample $(2 \mu \mathrm{g} /$ well $)$ and incubated at $37{ }^{\circ} \mathrm{C}$ for $48 \mathrm{hrs}$. Bio-activity was determined by measuring diameter of inhibition zones(DIZ) in $\mathrm{mm}$.

\section{RESULTS}

The results obtained from the Qualitative and Quantitative analysis was shown below.

\section{Qualitative analysis}

Table 1 shows the result of phytochemicals present in Alpinia officinarom Rhizome and Terminalia chebula Fruit. Except saponin and phenol, oil all the other phytochemicals were present sufficiently in Alpinia officinarom rhizome. Similarly, in Terminalia chebula fruit except oil content remaining phytochemicals were sufficiently present. 
Table 1. Qualitative analysis of Phytochemicals in Alpinia officinarum Rhizome and Terminalia chebula fruit

\begin{tabular}{lll}
\hline Phytochemicals Tested & $\begin{array}{l}\text { Alpinia officinarom } \\
\text { rhizome }\end{array}$ & $\begin{array}{l}\text { Terminalia chebula } \\
\text { fruit }\end{array}$ \\
\hline Glycosides & ++ & +++ \\
Flavonoids & +++ & ++ \\
Saponins & + & +++ \\
Steroids & ++ & +++ \\
Phenols & + & +++ \\
Alkaloids & ++ & +++ \\
Molish's test & +++ & ++ \\
Fehling's test & +++ & +++ \\
Oil test & + & + \\
Ferric chloride test & ++ & +++ \\
Potassium dichromate test & +++ & +++
\end{tabular}

Quantitative analysis using FTIR

Table 2 shows the results of Alpinia officinarom rhizome and Terminalia chebula Fruit. From the result, we could observe that, Alpinia officinarom rhizome contains higher amount of phenol and tannin. While in Terminalia chebula fruit phenol, flavonoid, tannin, saponin were observed in higher quantity with lesser amount of alkaloid.

Table 2. FTIR spectrum results of Alpinia officinarum Rhizome and Terminalia chebula fruit

\begin{tabular}{lll}
\hline Phytochemicals & $\begin{array}{l}\text { Spectrum Results of Alpinia } \\
\text { officinarum } \text { rhizome }\end{array}$ & $\begin{array}{l}\text { Spectrum Results of Terminalia } \\
\text { chebula fruit }\end{array}$ \\
\hline Total phenol as gallic acid equivalent & 3.6 & 85.3 \\
Total tannin as tannic acid equivalent & 1.2 & 60.3 \\
Total flavonoids as quercetin equivalent & BQL (LOQ: 0.1$)$ & 43.2 \\
Saponins & BQL (LOQ: 0.1$)$ & 15.12 \\
Alkaloids & BQL (LOQ: 0.1$)$ & 2.2 \\
\hline
\end{tabular}

BQL - Below Quantification Limit, LOQ - Limit of Quantification

\section{Quantitative analysis using HPLC}

The results of flavonoids analysed in Alpinia officinarom rhizome through HPLC was shown in Fig.1 and Table.3. Similarly, the HPLC results of Terminalia chebula fruit was depicted in Fig. 2 and Table.4.

\section{Quantitative analysis}

The results of secondary metabolites, phytonutrients, antioxidant activity of Alpinia officinarum rhizome and Terminalia chebula fruit was shown in Table.5.

Table. 5 shows the results of biochemical parameters analysed in Alpinia officinarum rhizome and Terminalia chebula fruit. Both Alpinia officinarum rhizome and Terminalia chebula fruit contain higher antioxidant activities such as nitric oxide scavenging (34.50\& $31.0 \mathrm{mg} / \mathrm{g}$, reducing power (39.75 and $52.50 \mathrm{mg} / \mathrm{g}$, total antioxidant activity 18.00 and $26.00 \mathrm{mg} / \mathrm{g}$ ). Among the secondary metabolites studied, phenolics was found to be higher in concentration in both the samples, while, the flavonoid content was low in both the samples. The nutrients like protein, carbohydrate and aminoacids were found to below in the experimented samples.

\section{Antibacterial activity}

Table. 6 shows the results of antibacterial activity of Alpinia officinarum rhizome and Terminalia chebula fruit. The result shows that the antibacterial activity was found to be higher with Alpinia officinarum rhizome compared to Terminalia chebula fruit. Alpinia officinarum rhizome showed significant antibacterial activity in all the four-test organism. Whereas, in Terminalia chebula fruit, the antibacterial activity was low with Bacillus punilus and the remaining organisms show significant antioxidant activity. Alpinia officinarum rhizome and Terminalia chebula fruit showed strong inhibitory 
activity on S.aureus causing bacteremia, sepsis and Salmonella typhi an intestinal bacteria.

Fig.1 HPLC chromatogram of Alpinia officinarom rhizome -Flavonoids

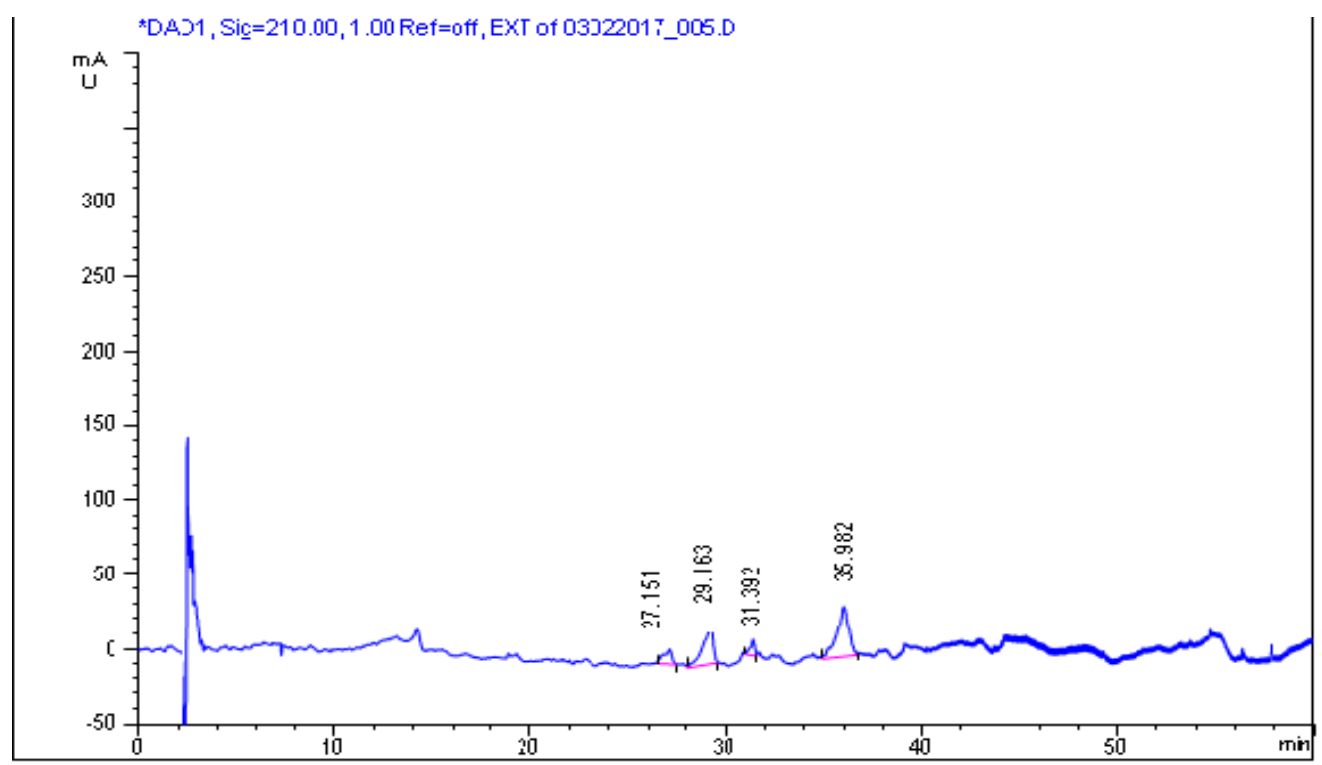

Table.3. Details of area percent / peak for Alpinia officinarom rhizome

\begin{tabular}{lllll}
\hline Peak & RT $(\min )$ & Height & Area & Area\% \\
\hline 1 & $27.151 \mid$ & 9.844 & 294.636 & 10.816 \\
2 & 29.163 & 27.167 & 903.698 & 33.175 \\
3 & 31.392 & 10.474 & 165.125 & 6.062 \\
4 & 35.982 & 33.205 & 1360.601 & 49.948 \\
\hline
\end{tabular}

Fig.2. HPLC chromatogram of Terminalia chebula fruit - Flavonoids

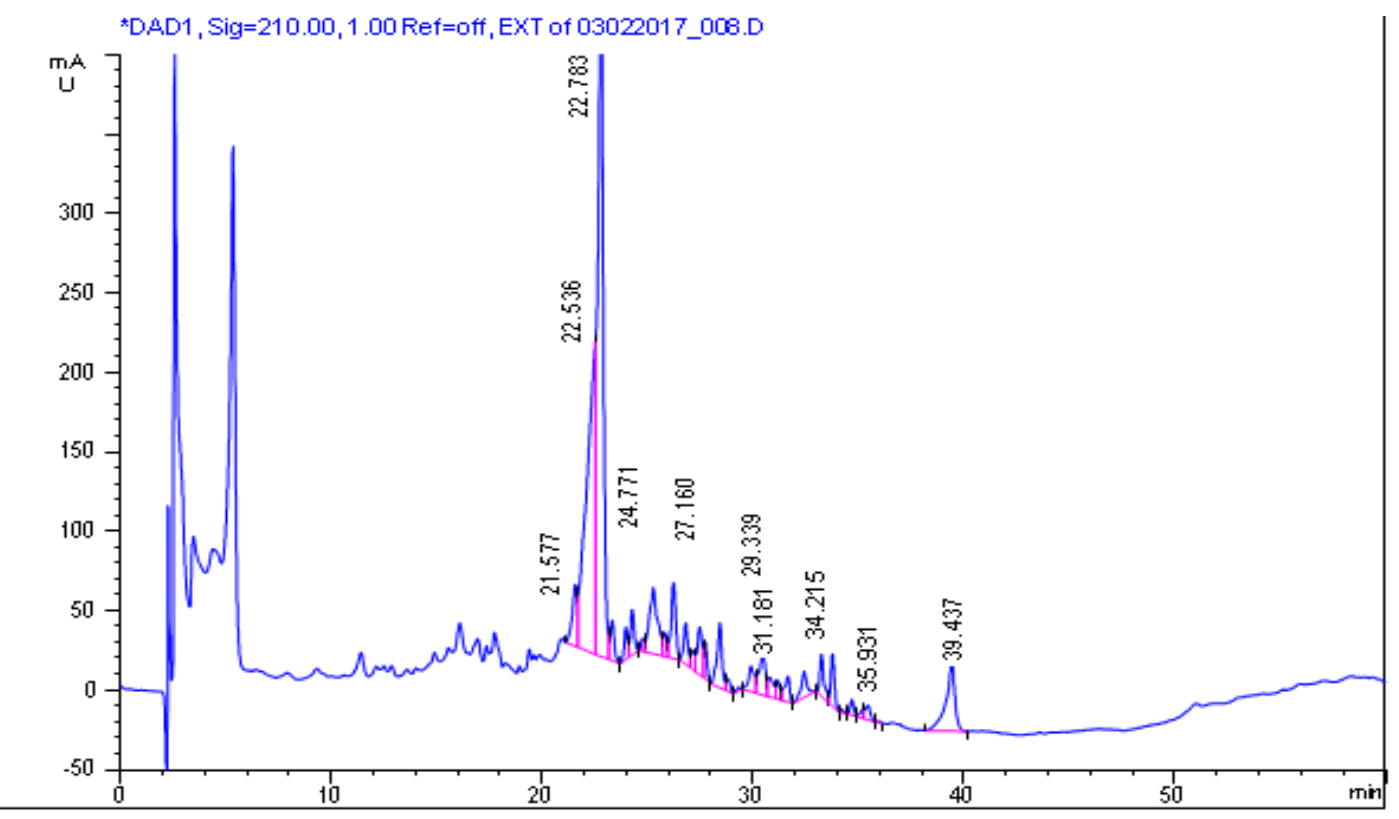


Table.4. Details of area percent / peak for Terminalia chebula fruit

\begin{tabular}{lllll}
\hline Peak & $\begin{array}{l}\text { RT } \\
(\mathbf{m i n})\end{array}$ & Height & Area & Area\% \\
\hline 1 & 21.577 & 39.134 & 0649.992 & 2.789 \\
2 & 22.536 & 196.611 & 5524.666 & 23.703 \\
3 & 22.783 & 426.811 & 7798.949 & 33.461 \\
4 & 23.322 & 25.470 & 0337.523 & 1.448 \\
5 & 23.974 & 20.326 & 0225.906 & 0.969 \\
6 & 24.272 & 28.706 & 0365.563 & 1.568 \\
7 & 24.771 & 08.317 & 0090.588 & 0.838 \\
8 & 25.278 & 41.631 & 1126.203 & 4.832 \\
9 & 25.820 & 15.300 & 0195.264 & 0.838 \\
10 & 26.234 & 47.506 & 0716.616 & 3.075 \\
11 & 26.813 & 25.897 & 0351.139 & 1.507 \\
12 & 27.160 & 11.898 & 0158.656 & 0.681 \\
13 & 27.476 & 30.156 & 0469.914 & 2.016 \\
14 & 27.734 & 23.387 & 0254.322 & 1.091 \\
15 & 28.435 & 40.571 & 0671.259 & 2.880 \\
16 & 28.808 & 07.741 & 0101.080 & 0.434 \\
17 & 29.339 & 02.326 & 0027.157 & 0.117 \\
18 & 29.909 & 16.233 & 00298.795 & 1.282 \\
19 & 30.476 & 27.970 & 0576.042 & 2.471 \\
20 & 30.794 & 12.539 & 0230.170 & 0.988 \\
21 & 31.181 & 12.098 & 0157.470 & 0.676 \\
\hline & & & & \\
\hline
\end{tabular}

Table 5. Analysis of Secondary metabolites, Phytonutrients, Antioxidant activity in Alpinia officinarum rhizome and Terminalia chebula fruit

\begin{tabular}{|c|c|c|}
\hline $\begin{array}{l}\text { Compounds / } \\
\text { Activity studied }\end{array}$ & $\begin{array}{l}\text { Alpinia officinarum rhizome } \\
\qquad(\mathrm{mg} / \mathrm{g})\end{array}$ & $\begin{array}{l}\text { Terminalia chebula fruit } \\
\text { (mg/g) }\end{array}$ \\
\hline \multicolumn{3}{|l|}{ Phytonutrients } \\
\hline Protein & $2.2 \pm 0.70$ & $2.4 \pm 0.00$ \\
\hline Amino acid & $1.3 \pm 0.56$ & $0.3 \pm 0.00$ \\
\hline Carbohydrate & $1.2 \pm 0.00$ & $4.5 \pm 0.848$ \\
\hline \multicolumn{3}{|c|}{ Secondary metabolites } \\
\hline Total phenolics & $33.0 \pm 0.00$ & $33.0 \pm 0.00$ \\
\hline Flavonoids & $2.00 \pm 0.00$ & $01.65 \pm 0.00$ \\
\hline \multicolumn{3}{|c|}{ Antioxidant activity } \\
\hline Nitric oxide & $34.50 \pm 0.00$ & $31.0 \pm 0.00$ \\
\hline Reducing power & $39.75 \pm 0.00$ & $52.5 \pm 1.22$ \\
\hline Total antioxidant & $18.00 \pm 2.12$ & $26.0 \pm 1.41$ \\
\hline
\end{tabular}

Values are Mean \pm SD for three experiments 


\section{Antibacterial activity of Alpinia officinarum rhizome and Teminalia cebula fruit}

\begin{tabular}{llll}
\hline Test organism & NCIM & $\begin{array}{l}\text { Alpinia officinarum } \\
\text { zone diameter }(\mathbf{m m})\end{array}$ & $\begin{array}{l}\text { Terminalia chebula fruit zone diameter } \\
(\mathbf{m m})\end{array}$ \\
\hline Escherichia coli & 2065 & 1.7 & 1.6 \\
Bacillus pumilus & 2327 & 1.9 & 0.8 \\
Salmonella typhi & 2501 & 1.8 & 1.2 \\
S taphylococcus aureus & 5345 & 1.9 & 1.7 \\
\hline
\end{tabular}

\section{CONCLUSION}

Alpinia officinarum rhizome and Terminalia chebula fruit possess antimicrobial and antioxidant activity which might be due to the presence of secondary metabolites in it. Analytical assessment also showed good amount of flavonoid content attributing for its pharmaceutical properties like application in the treatment of several infectious disorders.

\section{Acknowledgement}

The author wish to acknowledge Beloved Honorable Vice-Chancellor Prof. Dr.C.Swaminathan Avl and Respected Registrar Dr. M.Manivannan, Periyar University, Salem, Tamil Nadu, India for their administrative support as well as for offering lab facilities and also the authors thank Tamil Nadu Test House PVT Ltd, Chennai for performing analysis.

\section{REFERENCES}

1. 1.Ramakrishnappa K. Impact of Cultivation and Gathering of Medicinal Plants on Biodiversity:Case studies from India. In: Biodiversity and the Ecosystem Approach in Agriculture. Forestry and Fisheries [online], FAO, 2002.

2. 2.Masood E. Medicinal plants threatened by over-use. Nature. 385(6617); 1997:570.

3. 3.Rawat RBS. Medicinal Plants Sector in India with reference to Traditional Knowledge and IPR issues [online]. Paper presented at International Seminar for the Protection of Traditional Knowledge, New Delhi,April 2002.

4. 4.Wang Zhen-Gang, Ren J. Current status and future direction of Chinese herbal medicine. Trends in Pharmacological Sciences. 2002; 23(8): 347-348.

5. 5.Lee JS, Kim KA, Jeong SH, Lee SG, Park HJ "Antiinflammatory, anti-nociceptive, and anti-psychiatric effects by the rhizomes of Alpinia officinarum on complete Freund's adjuvant-induced arthritis in rats." J Ethnopharmacology. 2009; 126: 58-64.
6. 6.Konno K, Sawamura R, Sun Y, Yasukawa K, Shimizu T, Watanabe W, Kato M, Yamamoto RKM.“Antiviral activities of diarylheptanoids isolated from Alpinia officinarum against respiratory syncytial virus, poliovirus, measles virus, and herpes simplex virus type 1 in vitro"Nat. Prod. Commun. 2011; 6(12): 1881-1884.

7. 7.Hanneken A, Lin FF, Johnson J, Maher P. Flavonoids protect human retinal pigment epithelial cells from oxidative-stress-induced death. Invest. Ophthalmol. Vis. Sci.47;2006: 3164-3177.

8. 8.Nijveldt RJ, Nood E van, Hoorn DE van, Boelens PG, Klaske van Norren A and Leeuwen PA van. Flavonoids: a review of probable mechanisms of action and potential applications. Am. J. Clin. Nutr. 2001; 74(4):418-25.

9. 9.Knishinsky R. Prickly Pear Cactus Medicine, Treatments for Diabetes, Cholesterol and the Immune System. Rochester: Healing Arts Press; 2004.

10. 10.Ratha KK, Joshi GC. Haritaki (Chebulic myrobalan) and its varieties. Ayu 2013; 34: 331-4.

11. Baliga MS, Meera S, Mathai B, Rai MP, Pawar V and Palatty PL. Scientific validation of the ethnomedicinal properties of the ayurvedic drug triphala: areview. Chin. J Integr. Med.2012; 18:946-54.

12. Baliga MS Triphala. Ayurvedic formulation for treating and preventing cancer: a review. J. Altern. Complement. Med. 2010; 16: 1301-8.

13. 13.CSIR, The Wealth of India, A dictionary of Indian raw material \& industrial products, Vol. X, New Delhi: Publication and Information Directorate 2002;522-24.

14. 14.Varier. A dictionary of Indian raw materials \& Industrial products, New Delhi: Publication and Information Directorate Council of scientific \& Industrial research 2002; 387.

15. 15.Khare CP. Indian medicinal plants: An illustrated dictionary, Berlin, Springer-verlag: 2007; 652-3.

16. 16. Harborne JB. Phytochemical methods, $2^{\text {nd }}$ edition, Chapman and Hall, New York. 1984

17. 17.Kokate CK, Purohit AP, Gokhale SB. Pharmacognosy, $3^{\text {rd }}$ edition, Nirali Prakashan, Pune. 1995

18. 18.Kokoshi CL, Kokoshi RJ, Sharma FJ. Fluoresence of powdered vegetable drugs under UV Radiation. J Am Pharm Assoc. 1958; 47: 715-717. 
19. 19.Nabavi SM, Ebrahimzadeh MA, Nabavi SF, Hamidinia $A$ and Bekhradnia AR. Determination of antioxidant activity, phenol and flavonoids content of Parrotia persica Mey. Pharmacologyonline. 2008; 2: 560-567.

20. Mervat MM, Far El, Hanan A and Taie A. Antioxidant activities, total Anthocyanins, phenolics and flavonoids contents of some Sweet potato genotypes under stress of different concentrations of sucrose and sorbitol. Aust. J. Basic Appl. Sci., 2009; 3: 3609-16.

21. 21.Ebrahimzadeh MA, Nabavi SF and Nabavi SM. Antioxidant activities of methanol extract of Sambucus ebulus L.flower. Pak. J. Biol. Sci., 2009d; 12(5): 447-450.

22. 22.Yen GC, Chen HY. Antioxidant activity of various tea extracts in relation to their antimutagenicity. J. Agri. Food Chem., 1995; 43(1): 27-32
23. 23.Prieto $P$, Pineda $M$, and Aguilar $M$. Spectrophotometric quantitation of antioxidant capacity through the formation of a Phosphomolybdenum Complex: Specific application to the determination of vitamin E. Analytical Biochemistry. 1999; 269: 337-341.

24. 24.Hedge JE, Hofrelter BT. In: Carbohydrate chemistry, 17 Eds. Whistler RL, Be Miller JN, Academic press, New York. 1962

25. 25.Lowry $\mathrm{OH}$, Rosebrough NJ, Farr AL and Randall RJ. Protein measurement with Folin phenol Reagent, J Biol Chem., 1951; 193: 265-275.

26. 26.Yemm EW, Cocking EC and Ricketts RE. The determination of amino acids with ninhydrin. Analyst, 1955; 80: 209-214. 